\title{
EFFECT OF FEEDING HALF-FAT PROCESSED CHEESE SPREADS CONTAINING DIFFERENT TYPES OF WHEY PROTEIN CONCENTRATES ON PLASMA LIPIDS OF RATS Saleh, Zeinab A. ${ }^{1}$; M. E. Shenana ${ }^{2}$; Abeer A. Afifi'; G. F. El-Nagar ${ }^{2}$ and Safinaz El. Shibiny ${ }^{3}$ \\ ${ }^{1}$ Food Science and Nutrition Dept., National Research Centre, ${ }^{2}$ Food Science Dept., Banha University, Moshtohor, and \\ ${ }^{3}$ Dairy Dept., National Research Centre, Cairo, Egypt
}

\begin{abstract}
Half fat processed cheese spreads $(10 \mathrm{~g}$ fat $/ 100 \mathrm{~g}$ ) were prepared using blends with or without addition of $0.5 \mathrm{~g} / 100 \mathrm{~g}$ of particulated whey protein concentrates (PWPC), Simplesse ${ }^{\circledR} 100$ and whey protein concentrate (WPC). Also, full - fat processed cheese spread $(20 \mathrm{~g}$ fat $/ 100 \mathrm{~g}$ ) was prepared. Six groups of albino rats (8 animals each) were fed processed cheese spreads from different treatments and control on a basal diet for six weeks. The profile of blood serum lipids (total lipids, triglycerides, total cholesterol, HDL and atherogenic index) was determined in animals at the end of the experiment. The mean values of serum total cholesterol and triglycerides for the group fed processed cheese with PWPC were significantly lower than that of full fat and low fat groups. The atherogenic index [(total cholesterol - high density lipoprotein cholesterol)/high-density lipoprotein cholesterol] for the low fat group decreased significantly from 2.22 to $1.48(P<0.05)$ and 1.14 for low fat supplemented with PWPC group. The present study suggests that whey protein preparations had a lowering effect of blood lipids with PWPC being more effective. Keywords: blood lipid, processed cheese, whey protein concentrate, particulate.
\end{abstract}

\section{INTRODUCTION}

Dietary fats are known to play an important role in Cardiovascular disease risk (Hu,Manson, \& Willett, 2001). Arteriosclerosis progresses with age, it seems possible to delay and prevent its development through the improvement of diet.

In recently year' consumer demand for healthy and nutritionally balanced products has in especially food containing low fat, salt, and cholesterol levels, has increased (Shepherd \& Stakley, 1987; Lambert, 1991).

Milk fat plays essential roles in the organoleptic and functional properties in dairy products (De Roose, 1997). Reducing fat content in cheese may exhibit undesirable lack of flavor and development of a firm rubbery texture (Anderson \& Mistry, 1994). Also reduction of fat content changes cheese characteristics, resulting in a much harder and less smooth texture (Fusarpoli, 1989).

The use of fat replacers in cheese (Kebary et al., 1998 \& Hussein, 2000) as keeps the same functional and sensory properties as full fat cheeses has attracted great attention in past few years. Fat repracers can be classified into two categoriesnamely; microparticulated materials based on proteins (protein-based fat replacer) or that based on carbohydrate (carbohydrate-based fat replacer) (Huy ghebaert et al., 1996).

Fat replacers based on whey proteins have distinctive properties which allow them to act in foods in a manner similar to that of fat globules. 


\section{Saleh, Zeinab A. et al.}

These substitutes withstand interactions between particles (which suggests that their surface structure is similar to that of emulsified fat), and they interact with mouth surfaces to generate a sense of fatty substance.

Many epidemiological studies indicated that cheese consumption may have a protective role in various disease states (Roupas, 2001). Also, there is evidence that dairy foods as a source of fat and protein in the diet may not be associated with increased expression of heart disease, but the opposite (Ness et al., 2001; Sjogren et al., 2004). Recent studies has suggested that cheese is different, even from butter, in its influence on the serum cholesterol in humans, having minimal effects on plasma lipid profiles (Biong, et al., 2004).

Whey protein concentrate (WPC) is a food ingredient, generated from the processing of the cheese whey. Increased consumption and application of WPC has positive impacts on the dairy industry. WPC is a low-cost source of protein of a high nutritional value, which can be used in several foods such as drinks, baked goods and meat products. Sautier et al. (1983) reported that WPC has a high serum cholesterol lowering action as soybean protein in animal experiments. Nagaoka et al. (1992) also reported that the serum cholesterol lowering action of WPC is more powerful than that of soybean protein in several animal experiments. Nagaoka (1996) described $\beta$ lactoglobulin inhibited cholesterol absorption through changes of micellar cholesterol solubility in the intestine, accompanied by an increase of fecal steroid excretion. Inclusion of WPC in processed cheese spread has been successful in developing low fat processed cheese spread (El-Shibiny et al., 2007). However the effect of these additives on the nutritional quality of the products has not been studied has so far been restricted to animal models, mainly rats. The objective of this study was to investigate the effect of processed cheese supplemented with PWPC, WPC or Simplesse ${ }^{\circledR} 100$ on the plasma lipids profile in rats.

\section{MATERIALS AND METHODS}

\section{Materials:}

1-Ripened Ras cheese, obtained from Cairo market. The cheese was selected by the characteristic flavour of fully ripened Ras cheese.

2-Simplesse $\AA 100$ obtained from Kelco Biopolymers (Dorset House, Regent Park, Kingston Road, Leatherhead, UK)

3-Whey protein concentrate (WPC), was obtained from local market imported by El-Sayed Awad Al-Amreety Co. (Cairo) from VRS Foods Ltd.

4-Joha S4, SE and S9 emulsifying salts (BK Giulini Chemie $\mathrm{GmbH}$, Landenburg, Germaby) was obtained from the local market.

5-Sweet curd, prepared by rennet coagulation of ultrafiltered skimmed milk retentate .

\section{Preparation of whey protein/carrageenan particulate}

Whey from Emmental-type cheese ( $\mathrm{pH}$ 6.2-6.3) was obtained from Arab Dairy Co. (Kaha, Kaliubiea, Egypt). Whey was strained through cheese cloth to remove cheese fines and other suspended materials, and the fat was separated using Alfa Laval cream separator 107A, 450L/h. The defatted whey was then ultrafiltered using carbosep laboratory unit (SFEC, France) 
equipped with $0.7 \mathrm{~m}^{2}$ inorganic zirconium oxide membrane (molecular cut off 50,000 ). Ultrafiltration was carried out in a batch mode at $40^{\circ} \mathrm{C}$ and 0.5 and $0.3 \mathrm{MPa}$ inlet and outlet pressure, respectively. Ultrafiltration was continued to concentration factor $x 8$. The retentate was washed using tab water (amount $4 \mathrm{x}$ the retentate volume) and then re-concentrated up to total solids $18 \%$. The obtained retentate was used in the preparation of particulate whey protein/carrageenan concentrate (PWPC).

The method of El-Sheikh et al (2001) for the preparation of whey protein particulate was adopted with some modifications as follows: (a) sodium carrageenan was added to the whey retentate at the rate of $0.1 \mathrm{~g} 100$ $\mathrm{g}^{-1}(\mathrm{w} / \mathrm{w})$. The $\mathrm{pH}$ was adjusted to $\mathrm{pH} 5$ using $6 \mathrm{~N} \mathrm{HCl}$. (b) the whey retentate containing the carrageenan was heated at $85^{\circ} \mathrm{C}$ for $30 \mathrm{~min}$, and then homogenized at $60^{\circ} \mathrm{C}$ using 2 stage laboratory homogenizer (Rannie, Copenhagen) at 20 and $5 \mathrm{MPa}$ for the $1^{\text {st }}$ and $2^{\text {nd }}$ stage, respectively, and (c) the homogenized retentate/carrageenan mixture was then centrifuged at $5000 \mathrm{xg}$ for $10 \mathrm{~min}$. The precipitate was considered as a particulate whey proteins/carrageenan concentrate (PWPC). The compositional data (w/w) of the PWPC was $12.1 \%$ total solids, $6.72 \%$ protein, $0.79 \%$ ash and $4.59 \%$ carbohydrate.

\section{Manufacture of processed cheese spreads}

The amount of ingredients for manufacture of processed cheese spreads were calculated in order to fulfill the legal standard specification of the final product i.e full-fat ( 45\%) and low-fat ( 20\%) fat/dry matter (F/DM). The ingredients were mixed, placed in the processing kettle (Stephans Universal machine, Switzerland) of $2.5 \mathrm{~kg}$ capacity and then heated by direct steam up to $90^{\circ} \mathrm{C}$ with continuous mixing at $1400 \mathrm{rpm}$ for $5 \mathrm{~min}$. Heating was discontinued, the hot melted cheese was packaged manually in plastic leaded tops and stored at $5^{\circ} \mathrm{C}$ until analyzed and used for feeding rats. All the calculated ingredients were shown in Table 1

\section{Chemical analysis}

Fat, moisture and total nitrogen (TN) were determined according to the methods described by International Dairy Federation (IDF), 1991a, British Standard Institute (BSI), 1986a, and AOAC, respectively. All the results were average of three replicates.

Table (1) Formulation of ingredients (g) used in the preparation of full and low fat processed cheese spreads $(1 \mathrm{~kg})$ used for rats feeding experiments.

\begin{tabular}{|l|c|c|c|c|c|}
\hline Raw materials & $\begin{array}{c}\text { Full fat } \\
\text { cheese }\end{array}$ & $\begin{array}{c}\text { Half fat } \\
\text { cheese }\end{array}$ & $\begin{array}{c}\text { PWPC }^{*} \\
\text { cheese }\end{array}$ & $\begin{array}{c}\text { Simplesse }{ }^{\circledR 100} \\
\text { cheese }\end{array}$ & $\begin{array}{c}\text { WPC } \\
\text { cheese }\end{array}$ \\
\hline Ras cheese & 463.45 & 286.9 & 292.86 & 295.66 & 295.66 \\
\hline Retentate sweet curd & 331.06 & 507.6 & 519.42 & 524.39 & 524.39 \\
\hline Emulsifier Salt & 28.92 & 28.9 & 29.63 & 29.9 & 29.9 \\
\hline PWPC & - & - & 85.82 & & \\
\hline Simplesse $\AA 100$ & & & & 4.12 & \\
\hline WPC & & & & & 4.12 \\
\hline Added Water(ml) & 88.28 & 88.3 & - & 73.00 & 73.00 \\
\hline Condensed Water $(\mathrm{ml})$ & 88.28 & 88.3 & 72.26 & 73.00 & 73.00 \\
\hline
\end{tabular}

*PWPC: particulate whey protein concentrates 


\section{Saleh, Zeinab A. et al.}

\section{Animal feeding experiments:}

Forty-tow male albino rats with an average weight of $100 \mathrm{~g}$ were obtained from the Animal House of the National Research Center. All animals were housed individually in stainless steel cages and fed on a basal diet for one week, and then divided randomly into six groups each of seven rats. Each of these groups was allocated to one of six American Institute of Nutrition (AIN-93)-based rodent diets as shown in Table 2. One group received a basal diet (cholesterol-free diet) and served as a control group. The other five groups were fed on the basal diet with cholesterol added at a level of $1.0 \%(\mathrm{w} / \mathrm{w})$ (cholesterol-enriched diet) and supplemented with one of the following type of processed cheese: Full fat, half fat, half fat $+0.5 \%$ PWPC, half fat $+0.5 \%$ Simplesse ${ }^{\circledR} 100$ and half fat $+0.5 \%$ WPC.

All diets were balanced to contain $12.0 \%$ protein, and $5 \%$ fat except the full fat cheese diet (10\%) (diet No.2), with adequate vitamins and minerals provided by the AIN-93 formulation (Reeves, 1993) taking into account the moisture content of cheese. The diets were prepared and stored frozen for the duration of the experiment ( 6 weeks). The experimental diets given to the six groups are described in table (2).

Table 2: Composition of the experimental diets.

\begin{tabular}{|lcccccc|}
\hline Diet component (\%) $^{\text {Diet 1 }}$ & Diet 2 & Diet 3 & Diet 4 & Diet 5 & Diet 6 \\
Cheese $^{\text {a }}$ & 0 & 50 & 50 & 50 & 50 & 50 \\
Casein $^{\mathrm{b}}$ & 15 & 6.21 & 8 & 6.54 & 7.44 & 7.05 \\
Sucrose & 10 & 10 & 10 & 10 & 10 & 10 \\
Sunflower oil & 5 & 0 & 0 & 0 & 0 & 0 \\
Butter fat & 0 & 0 & 0 & 0 & 0 & 0 \\
AlN-93 minerals & 3.5 & 3.5 & 3.5 & 3.5 & 3.5 & 3.5 \\
AlN-93 vitamins & 1 & 1 & 1 & 1 & 1 & 1 \\
Fibre (a-cellulose) & 2 & 2 & 2 & 2 & 2 & 2 \\
L-cystine & 0.18 & 0.18 & 0.18 & 0.18 & 0.18 & 0.18 \\
Cholesterol powder & 0 & 1 & 1 & 1 & 1 & 1 \\
Cholic acid & 0 & 0.2 & 0.2 & 0.2 & 0.2 & 0.2 \\
Choline bitartrate & 0.25 & 0.25 & 0.25 & 0.25 & 0.25 & 0.25 \\
Cornstarch & 63.07 & 54.61 & 58.31 & 58.08 & 58.02 & 58.58 \\
\hline
\end{tabular}

${ }^{a}$ Cheese was analyzed to be $42.11,34.49,31.12,32.48$, and $32.83 \%$ total solid, $14.05,11.21$, $13.55,12.71$, and $12.09 \%$ protein (N_6.38, IDF recommended conversion factor for milk proteins), $20,12,12,12$, and $12 \%$ fat.

bCasein was analyzed to be $\mathbf{8 0 . 0 \%}$ protein (N_6.38).

Experimental diets and water were fed ad-libitum and feed intakes were recorded, body weights were measured weekly, and food intake was measured twice weekly. Feed efficiency ratios of the different diets were calculated as the Gain in body weight (g)/ Feed intake (g) according to Smith and Circle (1971).

At the end of the experiment rats were fasted over night and blood samples were collected in heparinized tubes under slight diethyl ether anesthesia by open heart puncture, and centrifuged at $3000 \mathrm{rpm}$ for $15 \mathrm{~min}$. The plasma was aliquoted and stored at $-20^{\circ} \mathrm{C}$ until used for analysis.

\section{Plasma analyses:}

Total plasma cholesterol was determined according to Richmond [1973], plasma high-density lipoprotein (HDL) Cholesterol by Lopes-Virella [1977] and triglycerides by Fossati \& Prinicip [1982]. The VLDL+LDL was 
calculated as follows: VLDL+LDL cholesterol=total cholesterol-HDL cholesterol. The atherogenic index was calculated as follows:

Atherogenic index $=($ Total cholesterol - high density lipoprotein cholesterol $) /$ high density lipoprotein cholesterol.

\section{Statistical analysis:}

Results are expressed as means \pm standard errors of means (SEM). Comparison between the means (of diet effects) was accomplished using a one-way ANOVA, followed by Duncan Multiple Range Tests for all variables (Duncan 1955). Differences between groups were considered significant at $\mathrm{p}<0.05$.

\section{RESULTS}

\section{Body weights and feed intake:}

There was no difference in body weights of rats from the different groups during the experimental period of 6 weeks as shown in table (3). Food intake was slightly higher for groups 3-6, which fed on diets supplemented with low fat cheese than for the control and full fat cheese supplemented groups, which were not different from each other. This increased feed intake probably reflected palatability of the low fat cheese diet. While the rats on the low fat cheese diet had a higher intake, there was no effect on body weight and feed efficiency ratio.

Table 3: Food intake, body weight gain and food efficiency ratio of rats on different groups

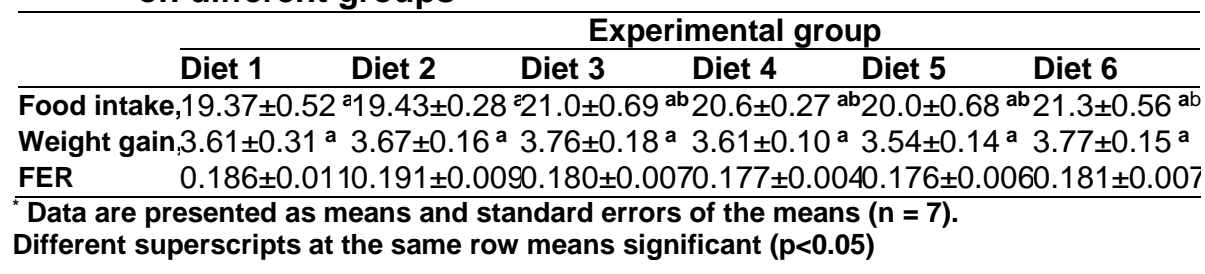

\section{Plasma assays:}

Plasma triglycerides from fasted rats were significantly higher in the full fat cheese diet No. 2 as compared with other diets $(P<0.01)$, as shown in table 4. Plasma cholesterol was lower in half fat diets 3-6 than diet 2 (full fat) $(P<0.05)$. The concentration of plasma cholesterol was significantly reduced from $106.6 \mathrm{mg} / 100 \mathrm{~mL}$ in the group 2 to a mean value of $84.2 \mathrm{mg} / 100 \mathrm{~mL}$ in rats fed diet 3 (half fat) and $77.6 \mathrm{mg} / 100 \mathrm{~mL}$ in group 4 (PWPC group). This decrease corresponds to a $21 \%$ and $27.2 \%$, respectively. However there was no significant difference in the level of plasma total cholesterol detected between the half fat diet and those supplemented with the different types of whey protein (Table 4). The diet supplemented with PWPC was more effective in reducing plasma cholesterol than the corresponding diet supplemented with Simplesse $₫ 100$ or WPC. There was no significant difference in the plasma HDLcholesterol level between the negative control group and other experimental groups at the end of the 6-week experimental period.

Rats fed on low fat, PWPC, Simplesse $\AA^{\circledR 100}$ or WPC diet had significantly lower plasma VLDL+LDL-cholesterol level than rats fed on the 
full fat diet. The PWPC diet was more effective in lowering plasma VLDL+LDL-cholesterol levels than the other two types of whey protein diets (Table 4).

The data in table 4 indicate that feeding low fat cheese decreased significantly the values of atherosclerotic index of rats by $33.3 \%, 48.6 \%$, $34.2 \%$ and $34.2 \%$, respectively for the four groups, below that in rats fed the full fat cheese. For rats fed on cholesterol-enriched diets and supplemented with PWPC diet was more effective in reducing the atherosclerotic index.

The total lipids was significantly reduced from $378 \mathrm{mg} / 100 \mathrm{~mL}$ in rats fed the full fat cheese to a mean value of $293 \mathrm{mg} / 100 \mathrm{~mL}$ in rats fed the low fat cheese and to a mean value of 276, 282 and $296 \mathrm{mg} \mathrm{100/mL} \mathrm{in} \mathrm{PWPC,}$ Simplesse $\circledast 100$ and WPC groups respectively. On the other hand, there was no significant difference in the plasma total lipids detected between the half fat or half fat supplemented groups and the normal control. (Table 4).

Table 4: Levels of plasma lipids in rats fed on different diets for six weeks

\begin{tabular}{|c|c|c|c|c|c|c|}
\hline \multirow[b]{2}{*}{ Diets } & \multicolumn{6}{|c|}{ Parameters } \\
\hline & $\begin{array}{l}\text { Triglyceride } \\
\text { (mg/dl) }\end{array}$ & $\begin{array}{l}\text { T.Cholesterol } \\
\text { (mg/dl) }\end{array}$ & $\begin{array}{c}\mathrm{HDL} \\
(\mathrm{mg} / \mathrm{dl})\end{array}$ & $\begin{array}{l}\text { VLDL+LDL } \\
\text { (mg/dl) }\end{array}$ & $\begin{array}{l}\text { Atherogenic } \\
\text { index }\end{array}$ & $\begin{array}{l}\text { Total Lipids } \\
\text { (mg/dl) }\end{array}$ \\
\hline$\overline{\text { Diet } 1}$ & $56.9 \pm 1.6^{a b}$ & $62.1 \pm 4.6^{\mathrm{a}}$ & $37.4 \pm 2.9^{\mathrm{a}}$ & $24.7 \pm 2.65^{a}$ & $0.68 \pm 0.07^{a}$ & $252 \pm 29.8^{a}$ \\
\hline Diet 2 & $73.3 \pm 3.5^{c}$ & $106.6 \pm 4.8^{c}$ & $33.5 \pm 2.2^{\mathrm{a}}$ & $73.1 \pm 3.15^{d}$ & $2.22 \pm 0.12^{c}$ & $378 \pm 24.3^{b}$ \\
\hline Diet 3 & $64.9 \pm 4.2^{b c}$ & $84.2 \pm 5.5^{b}$ & $35.3 \pm 4.4^{a}$ & $48.9 \pm 2.21^{c}$ & $1.48 \pm 0.14^{b}$ & $293 \pm 18.9^{a}$ \\
\hline Diet 4 & $48.5 \pm 3.2^{a}$ & $77.6 \pm 4.6^{b}$ & $37.6 \pm 4.2^{\mathrm{a}}$ & $40.0 \pm 2.67^{b}$ & $1.14 \pm 0.13^{b}$ & $276 \pm 27.5^{a}$ \\
\hline Diet 5 & $55.9 \pm 5.3^{a b}$ & $82.1 \pm 4.7^{b}$ & $33.9 \pm 2.7^{a}$ & $48.2 \pm 2.84^{c}$ & $1.46 \pm 0.09^{b}$ & $282 \pm 22.9^{a}$ \\
\hline Diet 6 & $57.7 \pm 4.2^{\mathrm{ab}}$ & $85.7 \pm 2.8^{b}$ & $33.7 \pm 2.5^{\mathrm{a}}$ & $52.0 \pm 1.54^{c}$ & $1.46 \pm 0.09^{b}$ & $296 \pm 19.7^{a}$ \\
\hline
\end{tabular}

Data are means \pm SE, $n=7$.

Different superscripts at the same column means significant $(p<0.05)$

\section{DISCUSSION}

Although the amount of food intake was higher for rats fed the half fat cheese diet, it had no significant impact on body weight gain relative to groups on other diets. This may have reflected the relative short time of the feeding study. Rats fed the diet containing cheese supplemented with Simplesse $₫ 100$ showed a trend (statistically significant) to less but not significant body weight gain per day than in rats fed the other diets.

The plasma cholesterol and triglyceride concentrations are significantly lower in rats on half fat cheese diets than in those on full fat cheese. When VLDL+LDL cholesterol level of different groups were compared, there was also a significant increase value of the group on full fat cheese diet relative to the basal diet-fed rats and those fed the half fat cheese diets. It may be concluded from this result that half fat cheese is a hypocholesterolemic agent relative to the full fat cheese.

In the present study, the results of these animal experiments suggested that the improvement of plasma lipid resulted mainly from the combination of half fat cheese and whey protein. Sautier et al. (1983) and Nagaoka et al. (1992) have reported the hypocholesterolemic activity of WPC. Kawase et al. (2000) also confirmed that WPC reduced the serum total cholesterol value and was dose-dependent. However, the amount of WPC added to the half fat cheese was limited. 
The plasma cholesterol-reducing effect of whey protein containing cheese could not be proved statistically in comparison to half fat cheese. This seemed to be attributed to the low amount of whey protein.

$\mathrm{HDL}$ is related to the transport of extra cholesterol from the organs, and its increase is effective in the prevention of arteriosclerosis. Although the total cholesterol level for the half fat cheese groups decreased, the change of $\mathrm{HDL}$ was not statistically significant $(P>0.05)$. However, the atherogenic index for the half fat cheese groups significantly decreased $(P<0.05)$. This diet effect is consistent with some reported observations in humans (Biong et al., 2004). Sjogren et al. (2004) have recently shown a more favourable LDL particle size distribution, predictive of reduced cardiovascular risk, in healthy men consuming dairy foods.

Thus, we conclude that it is possible to manufacture half fat processed cheese supplemented with WPC having a lipid improvement effect on humans as well as animals. These results indicate the potential of development of plasma fat processed cheese with therapeutic effects.

\section{Conclusions:}

This study has demonstrated that the inclusion of half fat processed cheese (with or without whey protein) in the diet of rats fed a cholesterolenriched diet had a marked affect on the levels of plasma lipids. The addition of PWPC to the Low fat processed cheese was more effective in reducing the level of plasma cholesterol. These hypocholesterolaemic effects of half fat cheese containing PWPC, which have been demonstrated in the rats in the present study, could make an effective and economic contribution in preventing hypercholesterolaemia, if these effects could be confirmed in human volunteers.

\section{REFERENCES}

Anderson, D. L and V.V. Mistry (1994). Reduced fat cheddar cheese from condensed milk 2- microstructure. J Dairy Sci. 77 (1) 7-15

AOAC 1990. Official Method of Analysis. 15 th Ed, Association of Official Analytical Chemistis INC., Artington, Virginia, USA.

Bank, J.; M. E. Y. Brechany and W. Christie (1989). The production of low fat Cheddar type cheese. J of the Society of Dairy Technology 42(1):6 - 9.

Biong, A. S., Muller, H., Seljeflot, I., Veierod, M. B., \& Pederson, J. I. (2004). A comparison of the effects of cheese and butter on serum lipids, haemostatic variables and homocysteine. British Journal of Nutrition, 92, 791-797.

BSI 1986: Determination of total solids contents (reference Methods) BS 770 part 10 .

De-Roos, K. B. (1997) How lipids influence food flavour. Food Technology. $51(1): 60-62$.

Duncan, D.B. (1955). Multiple range and multiple F-tests. Biometrics, 11,1-12.

Duxbury, D. D. (1992). Super stabilizer versatile as fat replacer. Food process $53: 39-42$.

El-Sheikh, M.M., Farrag, A.F., Shahein, N.M., and El-Shibiny, S. (2001). Low fat Domiati cheese with particulated whey protein concentrate (PWPC). Egyptian J. Dairy Sci., 29: 331-342. 


\section{Saleh, Zeinab A. et al.}

Fossati P., \& Prinicip L. (1982). Serum triglycerides determined colorimetrically with an enzyme that produces hydrogen peroxide. Clin. Chem, 28, 2077-2080.

Fusarpoli, F. (1989). Study on Rhelogical Characteristics and salt diffusivity in low fat Mozzarella cheese. Thesis, Universita Degli State, Milano, pp. $38-39$.

Giese, J. (1996). Fates, oils and fat replacers. Food Technol. 50: $78-84$.

Hewitt, L. (1993). The low fat boom. Food Manufacture 68: $23-26$.

Hu, F. B., Manson, J. E., \& Willett, W. C. (2001). Types of dietary fat and risk of coronary heart disease: A critical review. Journal of the American College of Nutrition, 20, 5-19.

Huyghebart, A. K. Dewettink and W. Degreyt (1996). Fat replacers. Bulletin of International Dairy federation No. $317: 10-15$.

International Dairy Federation (IDF) (1991). Nitrogen content of Milk and milk products. Annual sessions in Tokyo (Japan) October 1991.

Kawase, M. , Hashimoto, H. Hosoda, M., Morita, H., \& Hosono A. (2000). Effect of Administration of Fermented Milk Containing Whey Protein Concentrate to Rats and Healthy Men on Serum Lipids and Blood Pressure. J. Dairy Sci. 83:255-263.

Kebary, K. M. K.; Adeid, A. M. And Badawi, R. M. (1998): Impact of fat replacers on properties of low fat processed cheese spread. Proc. 7 th Egyptian Conf. Dairy Sci. and Techn.383 -401

Lambert, J. L. (1991). Consumer and light food products. Industrial Alimotaires et Agricoles 3: $154-157$.

Lopes-Virella, M.F., Stone, P., Ellis, S. \& Colwell, J.A. (1997). Cholesterol determination in high-density lipoproteins separated by three different methods. Clin. Chem., 23, 882-4.

Nagaoka, S. 1996. Studies on regulation of cholesterol metabolism induced by dietary food constituents or xenobiotics. J. Jpn. Soc. Nutr. Food Sci. 49:303-313.

Nagaoka, S., Kanamaru, Y., Kuzuya, Y., Kojima, T. \& Kuwata, T. (1992). Comparative studies on the serum cholesterol lowering action of whey protein and soybean protein in rats. Biosci. Biotech. Biochem. 56:1484-1485.

Ness, A. R., Davey-Smith, G., \& Hart, C. (2001). Milk, coronary heart disease and mortality. Journal of Epidemiology and Community Health, 55, 379-382.

Reeves, P. G., Nielson, F. H., \& Fahey, G. C. Jr. (1993). AIN-93 Purified diets for laboratory rodents: final report of the American Institute of Nutrition Ad. Hoc. writing committee on the reformulation of the AIN-76A rodent diet. Journal of Nutrition, 123, 1939-1951.

Richmond, W. (1973). Preparation and properties of a cholesterol oxidase from Nocardia sp. and its application to the enzymatic assay of total cholesterol in serum. Clin Chem., 19, 1350-6.

Roupas, P. (2001). Cheese consumption and health. Australian Dairy Foods, 23(2), 28-29. 
Safinas El. Shibiny, M. E. Shenana, G. F. El -Nagar and Sania Abdou (2007). Effect of fat content, fat replacers and emulsifying salts on half and low fat processed cheese spread. Accepted for publication in proceeding of the 4 th Saudi Conference and food nutrition, 10-12 December 2006, Riyadh, Saudi Arabic.

Sautier, C., K. Dieng, C. Flament, C. Doucet, J. P. Suquet, \& Lemonnier D. (1983). Effects of whey protein, casein, soya-bean and sunflower proteins on the serum, tissue and faecal steroids in rats. Br. J. Nutr. 49:313-319.

Shepherd, R. Stockley (1987). Nutrition knowledge, attitudes and fat consumption. 87: $615-619$.

Sjogren, P., Rosell, M., Skoglund-Andersson, C., Zdravkovic, S., Vessby, B., De Faire, U., Hamsten, A., Hellenius, M-L., \& Fisher, R. (2004). Milk derived fatty acids are associated with a more favourable LDL particle size distribution in healthy men. Journal of Nutrition, 134, 1729-1735.

Smith, A. K., \& Circle, S. J. (1971). Soybeans: Chemistry and technology vol. I, Proteins. AVI Publishing Company, INC., Wesport, Connecticut, USA. pp. 213-216.

Tseng, E., Potter, S.M. \& Picciano, M. F. (1990). Dietary protein source and plasma lipid profiles of infants. Pediatrics 85:548-552.

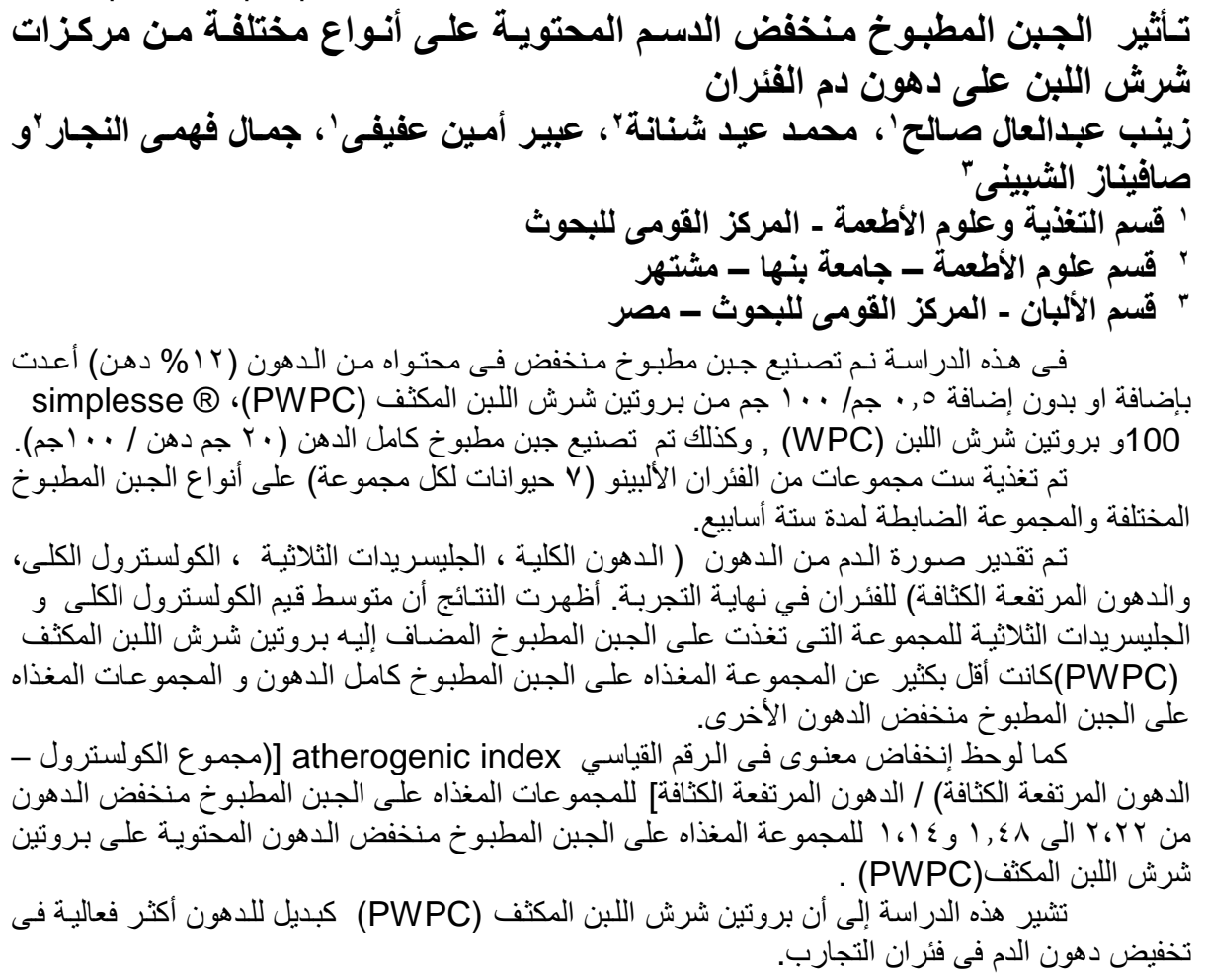

